\title{
Volatile profile and physical, chemical, and biochemical changes in fresh cut watermelon during storage
}

\author{
Perfil volátil e alterações físicas, químicas e bioquímicas na melancia minimamente \\ processada durante o armazenamento
}

\begin{abstract}
Andréa Luiza Ramos Pereira XISTO ${ }^{1 \star}$, Eduardo Valério de Barros VILAS BOAS ${ }^{1}$, Elisângela Elena NUNES²,

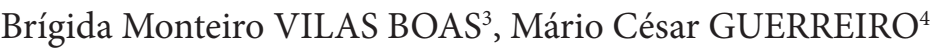

\begin{abstract}
Existing data about the aroma of fresh-cut watermelon and the metabolic changes that occur with minimal processing are scarce. Given the close relationship that exists between aroma, texture, and quality characteristics, it is necessary to investigate the changes in the volatile profile and texture of watermelon, a fruit extensively sold in supermarket chains throughout Brazil. The objective of this work was to analyze the volatile profile using solid phase microextraction (SPME) as well as texture changes in fresh-cut watermelon stored at $5{ }^{\circ} \mathrm{C}$ for ten days. Chromatography associated with sensory analysis (sniffing) led us to conclude that 9-carbon $\left(\mathrm{C}_{9}\right)$ alcohols and aldehydes are the major responsible for the flavor and aroma of minimally processed watermelon stored at $5 \pm 1{ }^{\circ} \mathrm{C} / 90 \pm 5 \% \mathrm{RH}$ for ten days, and also that the aroma diminishes in intensity with storage, but it does not affect the final quality of the product. It was noted that the amount of drained liquid, soluble pectin, and weight loss increased during storage concurrently with a reduction in firmness and a structural breakdown of the cells. Pectin methyl esterase activity remained constant and polygalacturonase activity was not detected.
\end{abstract}

Keywords: aroma; SPME-GC-MS; minimally processing; electronic microscopy.

\begin{abstract}
Resumo
Existe pouca informação a respeito do aroma de melancia minimamente processada e das alterações metabólicas que ocorrem com o processamento mínimo. Sabendo-se que há estreita relação entre aroma característico, textura e qualidade torna-se necessário o conhecimento a respeito das alterações do perfil volátil e textura deste produto, que é intensamente comercializado nas redes de supermercados do Brasil. Diante disso, o objetivo deste trabalho foi analisar o perfil volátil utilizando a técnica de microextração em fase sólida (SPME) e as modificações relacionadas à textura de melancia minimamente processada armazenada a $5{ }^{\circ} \mathrm{C}$, por dez dias. A cromatografia associada com análise sensorial ('sniffing') permitiu concluir que os álcoois e aldeídos com nove carbonos (C9) são os principais compostos responsáveis pelo sabor e aroma de melancia minimamente processada armazenada a $5 \pm 1{ }^{\circ} \mathrm{C} / 90 \pm 5 \% \mathrm{UR}$, durante dez dias e que a intensidade desse aroma diminui com o armazenamento, porém, sem comprometer a qualidade final do produto. Observou-se que o teor de líquido drenado, pectina solúvel e perda de massa aumentaram ao longo do armazenamento com concomitante diminuição da firmeza. A atividade de pectinametilesterase permaneceu constante e a de poligalacturonase não foi detectada.
\end{abstract}

Palavras-chave: aroma; SPME-GC-MS; processamento mínimo; microscopia eletônica.

\section{Introduction}

Interest in improving knowledge on the flavor and aroma of different types of food has increased recently, especially because they are related to product quality. Regarding fruits, aroma is one of the characteristics most appreciated by consumers, yet it is extremely sensitive to any changes in its chemical composition

The typical aroma of each fruit results from a combination of several volatile substances from various chemical categories that present different physicochemical properties and thresholds (THOMAZINI; FRANCO, 2000), such as esters, lactones, alcohols, acids, aldehydes, ketones, acetals, hydrocarbons and some phenols, and ethers and heterocyclic compounds (CHITARRA; CHITARRA, 2005; BALDWIN, 2002) meaning different biochemical pathways for aroma production, such as lipid peroxidation, aldehyde conversion into alcohols, methylerythritol 4-phosphate and mevalonate pathways, fermentation, etc. (BALDWIN, 2002; MA et al., 2007; PECH; LATCHÉ; van der REST, 2008).

The volatile compounds responsible for the characteristic flavor and aroma of fruits are produced via metabolic pathways that unfold during ripening, harvesting, and storage processes, and depend on many factors including species, variety, and type of technological treatment used (RIZZOLO; POLESELLO; POLESELLO, 1992). Therefore, it is important to investigate the chromatographic pattern of volatile substances in fresh products

\footnotetext{
Received 3/9/2010

Accepted 18/10/2011 (005030)

Laboratório de Bioquímica de Frutas e Hortaliças, Departamento de Ciência dos Alimentos, Universidade Federal de Lavras - UFLA,

Av. Álvaro Augusto Leite, 700, Monte Líbano, CEP 37200-000, Lavras, MG, Brasil, e-mail: andreaxisto@hotmail.com.br

2 Universidade Federal do Tocantins - UFT, Rua Badajós, Chacarás 69/72, Lote 7, CEP 77402-970, Gurupi, TO, Brasil

${ }^{3}$ Instituto Federal de Educação, Ciência e Tecnologia do Sul de Minas - IFSULDEMINAS, Rod. Machado, Paraguaçú, Km 3, Santo Antônio, CEP 37750-000, Machado, MG, Brasil

${ }^{4}$ Departamento de Química, Universidade Federal de Lavras - UFLA, Av. Álvaro Augusto Leite, 700, Monte Líbano, CEP 37200-000, Lavras, MG, Brasil

${ }^{*}$ Corresponding author
}

DOI: http://dx.doi.org/10.1590/S0101-20612012005000020 
since this knowledge will help identify the changes in volatile compounds that occur during storage (SHAMAILA et al., 1992) and processing.

Fresh-cut products are defined as fruits or vegetables that have been subjected to physical changes while maintaining the characteristics of a fresh product as well as the nutritional quality and microbiological safety (INTERNATIONAL..., 2010). Processing stages include selecting, sanitizing, peeling, and slicing. All of which should aim for a final product with great quality.

Damage caused by cutting not only increases respiration and ethylene production, but also causes an increase in other biochemical reactions responsible for changes in color, flavor, and aroma, as well as in texture and nutritional quality (BRECHT, 1995). Good quality fresh-cut products must have a fresh consistent appearance, acceptable texture, and characteristic flavor and aroma, in addition to having a reasonable useful shelf life to withstand handling throughout the distribution process (MORETTI, 2004).

Texture is one of the most important quality attributes in fruits and vegetables and is related to water content or turgidity and to the composition of the cellular wall. Any factor affecting these characteristics can potentially change the texture and consequently affect the quality of the final product.

Given the close relationship between characteristic aroma and quality in food, the metabolic changes occurring as a result of minimal processing, and the insufficient information available on aroma of fresh-cut watermelon, it is necessary to investigate the changes in the volatile profile of this product, which is widely sold in supermarket chains throught he country.

Bearing this in mind, the objective of this work was to analyze the volatile profile and to evaluate the tissue structure and texture changes in fresh-cut watermelon stored at $5{ }^{\circ} \mathrm{C}$ for ten days.

\section{Material and methods}

\subsection{Minimal processing}

The watermelons were obtained from a local store in Lavras, Minas Gerais state, washed with a neutral detergent to remove dirt, and then sanitized with sodium hypochlorite $200 \mathrm{mg} \cdot \mathrm{L}^{-1}$ for 15 minutes to avoid contamination during processing. They were placed on a workbench for 15 hours to allow excess solution to drain. The watermelons were manually cut into four lengthwise slices, and the pulp was scooped out by shaping into $3-\mathrm{cm}$ diameter balls using a fruit scooper. The slices and the scoops were drained using a previously sanitized household drainer for approximately five minutes in order to drain the excess juice. Next, the fresh-cut fruit $(100 \mathrm{~g})$ was placed in a sturdy-lid polypropylene container $(15 \times 11.5 \times 4.5 \mathrm{~cm})$ and stored it in a cold chamber at $5 \pm 1{ }^{\circ} \mathrm{C}$ and relative humidity of $95 \pm 5 \%$ for 10 days.

\subsection{Extraction, quantification, and identification of volatile compounds}

The volatile compounds were extracted using the Solid Phase Microextraction technique (SPME). A $75 \mu \mathrm{m}$ carboxen- polydimethylsiloxane fiber (CAR/PDMS) was used for the partition of the volatile compounds present in the sample. The fibers were exposed to the headspace of a glass vial $(5 \mathrm{~mL})$ containing $1 \mathrm{~mL}$ of juice made with fresh-cut watermelon. After 15 minutes of exposure to the fiber at room temperature, the syringe was immediately placed into an injector port of the gas chromatograph, in which volatile compounds were desorbed at $220^{\circ} \mathrm{C}$ for 2 minutes.

In order to quantify the volatile compounds, a Varian CP3800 gas chromatograph equipped with a flame ionization detector was used. The chromatographic conditions were: $30 \mathrm{~m} \times 0.25 \mathrm{~mm}$ and $0.25 \mu \mathrm{m}$ fused silica capillary column, $5 \%$ diphenyl and $95 \%$ polydimethysiloxane stationary phase (EQUITY-5), splitless injection, hydrogen carrier gas, flow rate $1.0 \mathrm{~mL} /$ minute, injector temperature $220{ }^{\circ} \mathrm{C}$, detector temperature of $260{ }^{\circ} \mathrm{C}$, and initial column temperature of $40{ }^{\circ} \mathrm{C}$ with an increase of $3{ }^{\circ} \mathrm{C}$ per minute up to $240{ }^{\circ} \mathrm{C}$. The concentration of components (\%) was calculated based on the total area of their respective peaks in relation to the total area of all sample components (area normalization).

The volatile compounds were identified using gas chromatography with mass spectrometry (GC/MS). Hence, a GC-17A Shimadzu apparatus with a QP5050A mass-selective detector was used under the following operating conditions: $30 \mathrm{~m} \times 0.25 \mathrm{~mm}$ fused and $0.25 \mu \mathrm{m}$ silica capillary columns, $5 \%$ diphenyl and $95 \%$ siloxane; initial column temperature of $40^{\circ} \mathrm{C}$ with an increase of $3{ }^{\circ} \mathrm{C}$ per minute up to $240^{\circ} \mathrm{C}$; helium carrier polydimethysiloxane stationary phase (DB5); injector temperature $220^{\circ} \mathrm{C}$ gas, flow rate $1.8 \mathrm{~mL} /$ minute; $1: 8$ split ratio; $1 \mu \mathrm{L}$ injected volume; and $100 \mathrm{KPa}$ initial pressure.

The MS parameters were: mass-selective detector operating by electron impact with ionization energy of $70 \mathrm{eV}$; scan speed $1000 \mathrm{~m} / \mathrm{z} / \mathrm{s}$; scan interval 0.5 fragments/second; and fragment range of 29 to $600 \mathrm{Da}$. Each component was identified by comparing its mass spectrum to existing spectra in the literature (ADAMS, 2007) and with those from the equipment database (Wiley 7). They were also identified by comparing Kovats retention indices against those in the literature. The Kovats retention indices were determined using a calibration curve of an $n$-alkane series (C8-C22) injected under the same chromatographic conditions as those of the samples.

The aroma perception analysis (sniffing analysis) was conducted at the Analyses and Chemical Prospecting Center of the Department of Chemistry of UFLA, Lavras, MG using a Varian CP3800 gas chromatograph under the same operating conditions as those used for the quantification of volatile compounds. Initially, the samples were eluted in the chromatographic column to detect peaks and retention times. The samples were again injected for the perception and description of the aroma of each compound to be analyzed by tasters. The analysis was performed by five untrained tasters who were familiar with sensory analysis of food.

\subsection{Scanning electron microscopy}

Five scoops were randomly removed from each container and manually cut crosswise approximately $1 \mathrm{~mm}$ thick; they 
were then immersed in a Karnovisky modified fixative solution (glutaraldehyde $2.5 \%$, paraformaldehyde $2.0 \%$, and cacodylate buffer $0.05 \mathrm{M}, \mathrm{pH} 7.2$ ) and stored in a cold chamber. Next, they were transferred to a cryoprotective liquid (glycerol 30\%) for 30 minutes and frozen in liquid nitrogen.

The fragments were transferred to a solution of $1 \%$ osmium tetroxide ( 3 drops) and water. They were left to rest for one hour, rinsed three times using distilled water and subsequently dehydrated in an acetone series $(25,50,75,90$, and $100 \%$, three times) and transferred to a critical point apparatus. The specimens were mounted onto aluminum stubs with carbon tape attached to thin aluminum foil, and were gold sputtered and observed under a LEO EVO 40 XVP scanning electronic microscope. Several images were generated and digitally recorded for each sample under varying magnitudes with the equipment operating at $20 \mathrm{kv}$ and a working distance of $15 \mathrm{~mm}$.

\subsection{Physical, chemical, and biochemical analyses}

- Drained liquid - The liquid drained inside the container was collected with the help of a previously weighed filter paper, and the weight of the drained juice in relation to the product mass was determined using an analytical scale. The results were expressed in percentage;

- Soluble pectin - Pectin was extracted according to a technique described by McCready and McComb (1952), and was colorimetrically determined according to Bitter and Muir (1962). The results were expressed in $g$ of galacturonic acid. $100 \mathrm{~g}^{-1}$ of pulp;

- Weight loss - An analytic scale was used to obtain the individual mass of each scoop in the beginning of the storage period and on the day of analysis. The results were expressed in percentage;

- Firmness - A Stable Micro System TA.XT2i computerized digital texture analyzer equipped with a $5 \mathrm{~mm}$ diameter probe was used. Two measurements of each stored scoop were taken. The results were expressed in Newtons $(\mathrm{N})$;
- Pectin methyl esterase activity (PME) - PME was extracted according to the method described by Buescher and Fumanski (1978), with alterations by Vilas Boas et al. (2000). PME activity was measured according to Hultin, Sun and Bulger (1966) and Ratner, Goren and Monseline (1969) and alterations made by Vilas Boas et al. (2000). One unit of PME was defined as the amount of enzyme capable of catalyzing demethylation of pectin corresponding to the consumption of $1 \mathrm{nmol} \mathrm{NaOH} /$ minute/g, under the experiment conditions;

- Polygalacturonase activity (PG) - PG was extracted according to the Buescher and Fumanski method (BUESCHER; FUMANSKI, 1978), with alterations made by Vilas Boas et al. (2000). PG activity was measured according to Markovic et al. (1975), with alterations made by Vilas Boas et al. (2000). The enzymatic activity was expressed in nanomol of galacturonic acid/minute/g of fruit.

\section{Results and discussion}

The dominant components detected by solid phase microextraction were six- $\left(\mathrm{C}_{6}\right)$ and nine-carbon $\left(\mathrm{C}_{9}\right)$ alcohols and aldehydes (Table 1), similar to those found in watermelon extracts (BEAULIEU; LEA, 2006; YAJIMA et al., 1985; KIM; LEE; KIM, 1999; PINO; MARBOT; AGUERO, 2003) and in other cucurbits (BEAULIEU, 2006).

Despite often being regarded as oxidation products (MATSUI et al., 1997; RILEY; THOMPSON, 1998), $\mathrm{C}_{6}$ and $\mathrm{C}_{9}$ compounds have also been thought to impact on watermelon and melon. Nine-carbon compounds have been attributed aromas typical of watermelon, melon, and other cucurbits. For instance, (Z)-3-nonenol imparts a fresh melon scent, (Z,Z)-3,6nonadienol imparts a sweet peeled watermelon scent, $(E, Z)$ 2,6-nonadienal and a cucumber scent and (E)-2-nonenal, a pervasive oily odor. (Z,Z)-3,6-nonadienol alcohol was found to contribute more to the watermelon scent (YAJIMA et al., 1995). These reports agree with the results of this study since with the help of chromatography/olfactometry it was concluded that

Table 1. Kovats Index, major ions from fragmentation by mass spectrometry, and aroma attributes of volatile compounds identified in fresh-cut watermelon stored at $5{ }^{\circ} \mathrm{C}$ for 10 days.

\begin{tabular}{lccl}
\hline \multicolumn{1}{c}{ Compound } & $\mathrm{KI}^{1}$ & Major ion m/z (relative intensity) & \multicolumn{1}{c}{ Attributes } \\
\hline Acetaldehyde & 524 & $44(100) ; 43(37) ; 41(22) ; 40(16)$ & Aldehydic \\
Hexanal & 804 & $44(100) ; 41(94) ; 56(69) ; 43(61)$ & Green, floral \\
Hexanol & 877 & $56(100) ; 43(72) ; 41(50) ; 42(44)$ & Green, cut grass \\
Heptanol & 969 & $43(100) ; 56(48) ; 42(36) ; 41(32)$ & Green, grassy, floral \\
6-methyl-5-hepten-2-one & 990 & $43(100) ; 41(46) ; 55(25) ; 69(20)$ & Fruity, sweet \\
Ethyl hexanoate & 1001 & $43(100) ; 88(83) ; 60(46) ; 41(40)$ & Fruity \\
Nonanal & 1102 & $41(100) ; 44(93) ; 57(74) ; 56(58)$ & Citrus, rose, green \\
Z-3-nonenol & 1157 & $41(100) ; 55(70) ; 68(54) ; 67(47)$ & Citrus, melon \\
(E,Z)-2,6-nonadienal & 1159 & $41(100) ; 70(37) ; 69(36) ; 55(30)$ & Watermelon, cucumber, green \\
(Z,Z)-3,6-nonadienol & 1160 & $41(100) ; 67(97) ; 55(58) ; 79(41)$ & Watermelon, fruity, fresh, cucumber \\
Z-6-nonenol & 1161 & $41(100) ; 55(70) ; 68(54) ; 67(47)$ & Melon, green \\
E-2-nonenal & 1167 & $41(100) ; 43(71) ; 55(71) ; 67(71)$ & Pervasive \\
Nonanol & 1174 & $41(100) ; 43(79) ; 56(76) ; 55(67)$ & Citrus, rose \\
Ethyl octanoate & 1198 & $88(100) ; 55(75) ; 43(69) ; 41(65)$ & Fruity \\
\hline
\end{tabular}

${ }^{1} \mathrm{KI}=$ Kovats Index based on retention times of identified compounds, calculated by a linear equation between each pair of the hydrocarbons chain $\left(\mathrm{C}_{5}-\mathrm{C}_{22}\right)$ 
characteristic watermelon scent is mainly imparted by ninecarbon aldehydes and alcohols. Bearing this in mind, an analysis of variance for $\mathrm{C}_{9}$ compounds was performed to evaluate their behavior during storage.

No significant difference was found for Z-3-nonenol percentages during storage.

The percentages of (E,Z)-2,6-nonadienal (Figure 1), (Z,Z)-3,6-nonadienol (Figure 1), Z-6-nonenol (Figure 2), and E-2-nonenal (Figure 2) presented significant difference during storage.

A decrease in the percentage of these compounds was observed as storage time progressed, which can be correlated to the sensory analysis of total aroma. The tasters detected a slight decrease in intensity in the watermelon aroma towards the end of storage period in relation to the initial aroma of the fresh-cut watermelons.

Most volatile compounds in vegetables simply dissipate in the air to be finally degraded by biological, chemical, and photochemical reactions. In minimal processing, the cutting of tissues releases precursory substances of aromatic compounds, which in turn become volatile through enzymatic or oxidative

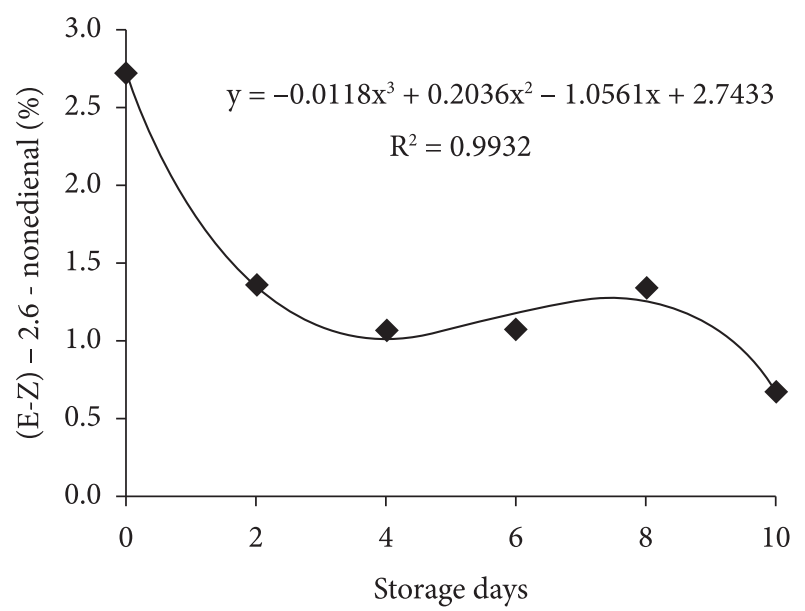

reactions. Some natural compounds can dissipate quickly, resulting in products with poor flavor and aroma if compared to fresh fruits and vegetables (CHITARRA; CHITARRA, 2005).

Another compound observed was 6-methyl-5-hepten-2one, imparting a herbal, green, oily and pungent aroma. This compound has been recovered from several types of vegetables including apple, tomato, and watermelon. According to the literature, it is considered an oxidative by-product or a product obtained from the degradation of lycopene, $\alpha$-farnesene, citral, or conjugated trienols (WHITAKER; SAFTNER, 2000; WOLKEN; HAVE; WERF, 2000; LEWINSOHN et al., 2005). Hence, the detection of 6-methyl-5-hepten-2-one ketone is not unexpected due to the high concentration of lycopene found in watermelon (data not shown).

Figure 3 illustrates the tissue structure of fresh-cut watermelon in the beginning and end of the storage period. In the beginning of the storage period, a high concentration of liquid was observed among the cells in the tissue structure of the scoops, as indicated by the turgid and tender appearance of the fresh-cut product (Figure 3a). At the end of the storage period, we observed changes in the tissue structure probably

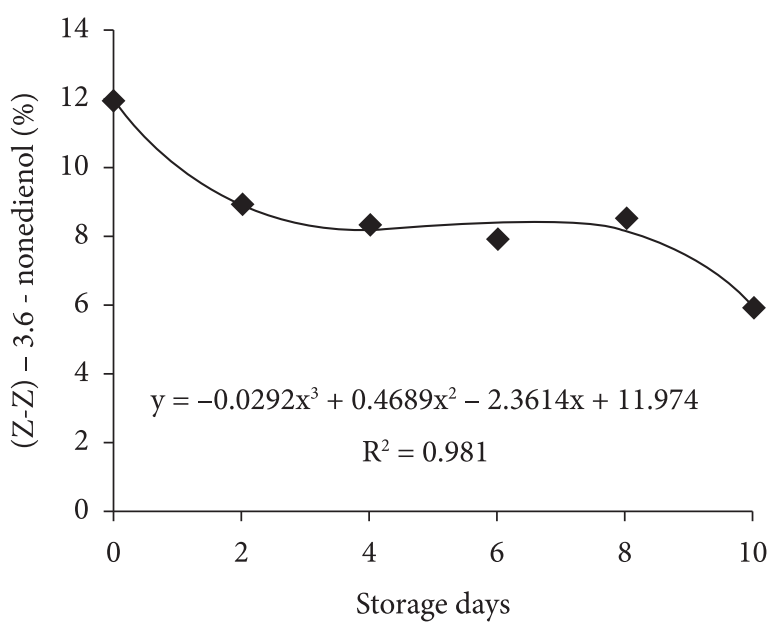

Figure 1. Mean values and regression equation for (E-Z)-2,6-nonedienal and (Z-Z)-3,6-nonedienol as found in fresh-cut watermelon, stored at $5 \pm 1{ }^{\circ} \mathrm{C} / 90 \pm 5 \% \mathrm{RH}$ for 10 days, via SPME GC-MS.
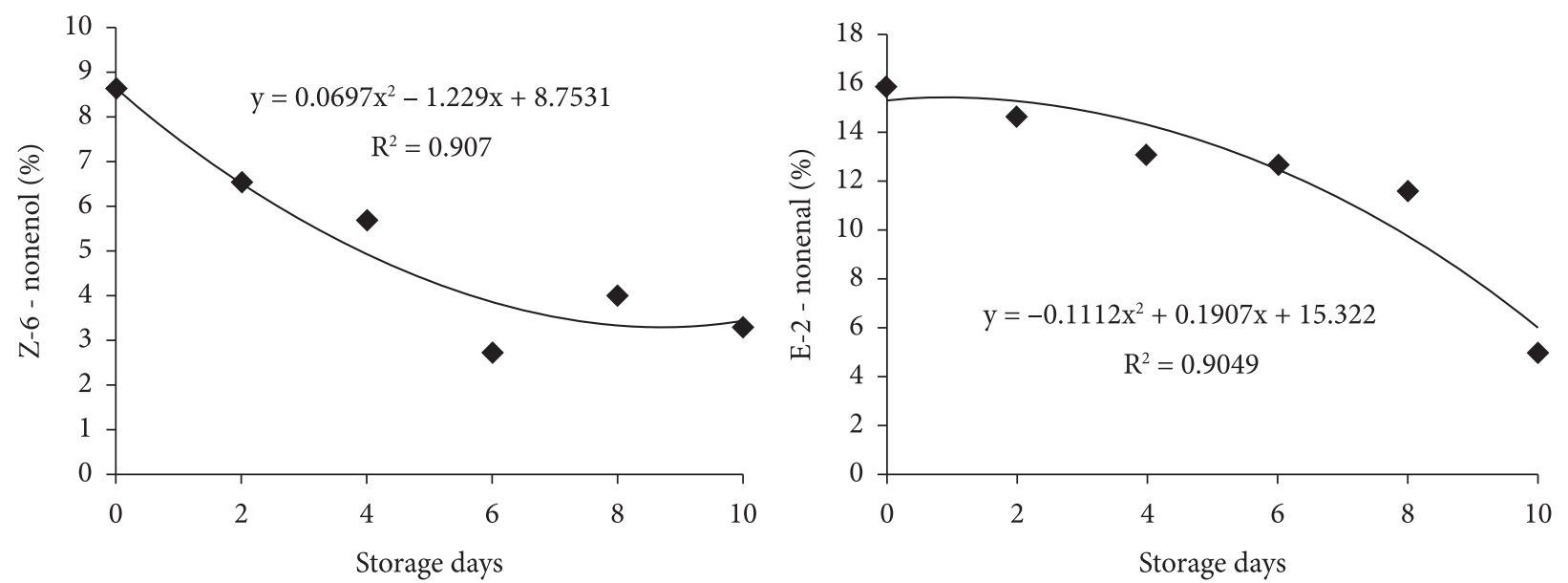

Figure 2. Mean values and regression equation for Z-6-nonenol and E-2-nonenal as found in fresh-cut watermelon, stored at $5 \pm 1{ }^{\circ} \mathrm{C} / 90 \pm 5 \%$ RH for 10 days, via SPME GC-MS. 


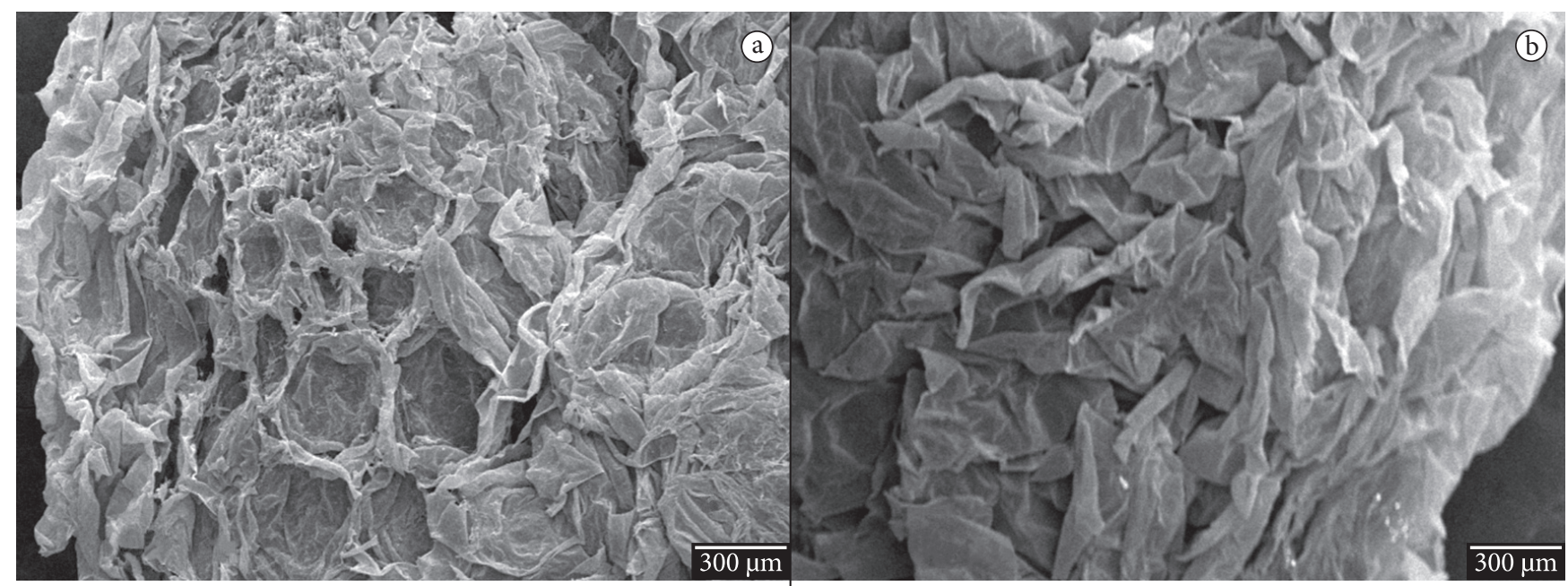

Figure 3. Scanning electromicrograph of the tissue structure of fresh-cut watermelon stored at $5 \pm 1{ }^{\circ} \mathrm{C} / 90 \pm 5 \% \mathrm{RH}$, for 10 days. a) Start of storage time; and b) End of storage time.
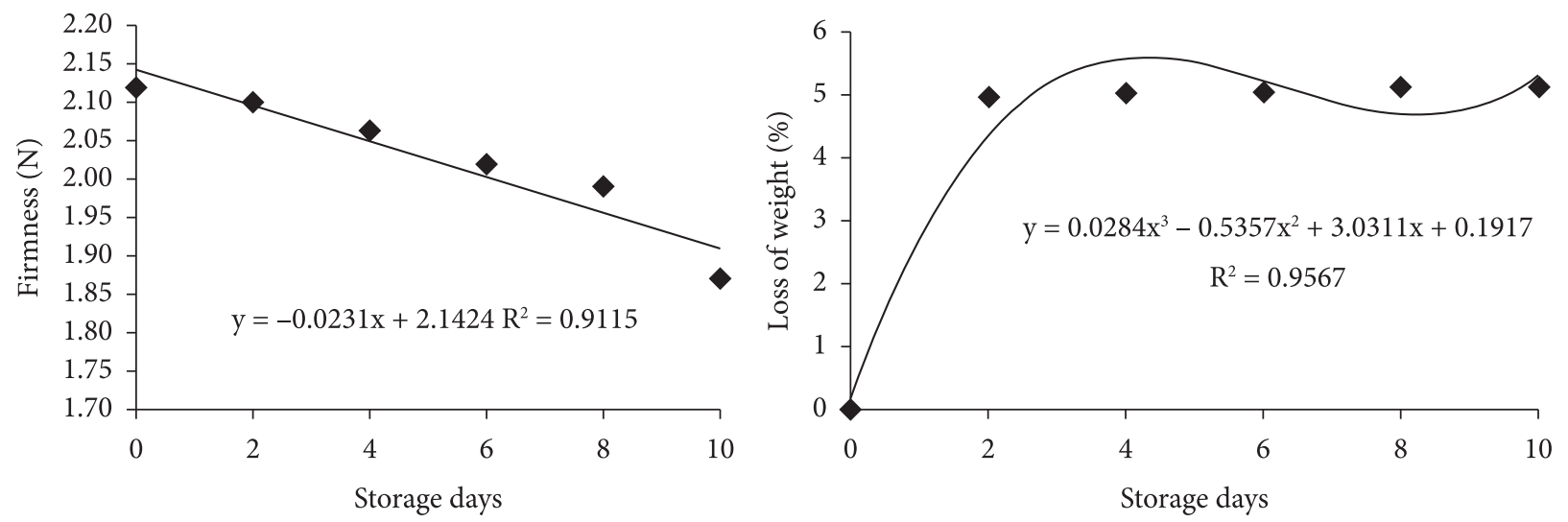

Figure 4. Mean value of drained liquid, soluble pectin, loss of weight and firmness fresh-cut watermelon stored at $5 \pm 1{ }^{\circ} \mathrm{C} / 90 \pm 5 \% \mathrm{RH}$, for ten days.

due to mass loss and release of liquid (Figure $3 \mathrm{~b}$ ) caused by cell decompartmentalization.

In this study, a linear increase in the amount of liquid released inside the container during storage (Figure 4) was verified. In a study to evaluate the volume of juice released from slices of fresh-cut pineapple, Marrero and Kader (2006) also observed a linear increase in the amount of liquid released.

The concentration of soluble pectin tended to increase during storage while firmness decreased concurrently, suggesting softening of the pulp of the fresh-cut watermelon (Figure 4). A similar behavior was observed in fresh-cut melon (ARRUDA; JACOMINO; KLUGE, 2003).

As storage progressed, the watermelon scoops presented increased loss of weight (Figure 4). Greater loss of water results in withering, loss of visual quality, and in change of texture. The losses observed in this study, however, did not affect the product appearance.

Storage did not significantly influence the activity of pectin methyl esterase, which was 946.85 (U/g/minute) on average. The activity of polygalacturonase was not detected in this study.
Indications suggest loss of texture in minimally processed products as storage period progresses, and this loss is thought to be one of the limiting factors that reduce the useful life of fresh-cut products (BEAULIEU; GORNY, 2001); it has been detected in other products including papaya, kiwi fruit, pear, and melon (KARAKURT; HUBER, 2003; VAROQUAX et al., 1990; SOLIVA-FORTUNY et al., 2002).

\section{Conclusions}

Chromatography associated with sensory analysis (sniffing) led to the conclusion that $\mathrm{C}_{9}$ aldehydes and alcohols are primarily responsible for the flavor and aroma of fresh-cut watermelon stored at $5 \pm 1{ }^{\circ} \mathrm{C} / 90 \pm 5 \% \mathrm{RH}$ for ten days and that the aroma diminished in intensity as storage progressed, even though it did not affect the final quality of product.

Scanning electronic microscopy demonstrated that the tissues of fresh-cut watermelon stored for ten days presented a disorganized structure.

A loss of texture occurred in the fresh-cut watermelon during storage, yet it proved insufficient to be regarded as a limiting factor to reduce its useful life or affect its quality. 


\section{Acknowledgements}

The authors are grateful to the National Council of Scientific and Technological Development $(\mathrm{CNPq})$ for the financial support.

\section{References}

ADAMS, R. P. Identification of essential oil components by gás chromatography/mass spectroscopy. 4th ed. Carol Stream: Allured Publishing Corporation, 2007. 804 p.

ARRUDA, M. C. ; JACOMINO, A. P.; KLUGE, R. A. Temperatura de armazenamento e tipo de corte para melão minimamente processado. Revista Braileira de Fruticultura, v. 25, n. 1, p. 74-76, 2003. http:// dx.doi.org/10.1590/S0100-29452003000100022

BALDWIN, E. Fruit flavor, volatile metabolism and consumer perceptions. In: KNEE, M. (Ed.). Fruit quality and its biological basis. Sheffield: Sheffield Academic Press, 2002. 277 p.

BEAULIEU, J. C.; LEA, J. M. Characterization and semiquantitative analysis of volatiles in seedless watermelon varieties using solidphase microextraction. Journal Agricultural Food Chemistry, v. 54, p.7789-7793, 2006. PMid:17002453.http://dx.doi.org/10.1021/jf0606631

BEAULIEU, J. C. Effect of cutting and storage on acetate and nonacetate esters in convenient, ready-to-eat fresh-cut melons and apples. Hortscience, v. 41, p. 65-73, 2006.

BEAULIEU, J. C.; GORNY, J. R. Fresh-cut fruit. In: GROSS, K. C.; SALTVEIT, M. E.; WANG, C.Y. (Ed.). The commercial storage of fruits, vegetables, and florist and nursery stocks. Washington: USDA, 2001. (USDA Handbook, 66).

BITTER, T.; MUIR, H. M. A modified uronic acid carbazole reaction. Analytical Chemistry, v. 34, p. 330-334, 1962.

BRECHT, P. E. Physiology of lightly processed fruits and vegetables. Hortscience, v. 30, n. 1, p. 18-22, 1995.

BUESCHER, R.W.; FURMANSKI, R. J. Role of pectinesterase and polygalacturonase in the formation of woolliness in peaches. Journal of Food Science, v. 43, n. 1, p. 264-266, 1978. http://dx.doi. org/10.1111/j.1365-2621.1978.tb09788.x

CHITARRA, M. I. F.; CHITARRA, A. B. Pós-colheita de frutos e hortaliças: fisiologia e manuseio. 2. ed. Lavras: UFLA, 2005. 785 p

HULTIN, H. O.; SUN, B.; BULGER, J. Pectin methyl esterases of the banana. Purification and properties. Journal of Food Science, v. 31, n. 3, p. 320-327,1966. http://dx.doi.org/10.1111/j.1365-2621.1966.tb00500.x

INTERNATIONAL FRESH-CUT PRODUCE ASSOCIATION - IFLA. Processamento mínimo. 2010. Disponível em: <www.fresh-cut. org >. Acesso em: 26 jul. 2010.

KARAKURT, Y.; HUBER, D. J. Activities of several membrane and cell-wall hydrolases, ethylene biosynthetic enzymes, and cell wall polyuronide degradation during low-temperature storage of intact and fresh-cut papaya (Carica papaya) fruit. Posthharvest Biology and Technology, v. 28, p. 210-229, 2003. http://dx.doi.org/10.1016/ S0925-5214(02)00177-1

KIM, K. S.; LEE, H. J.; KIM, S. M. Volatile flavor components in watermelon (Citrillus lanatus S.) and Oriental Oriental melon (Cucumis melo L.). Korean Journal Food Science Technology, v. 31, p. 322-328, 1999.

LEWINSOHN, E. et al. Carotenoide pigmentation affects the volatile composition of tomato and watermelon fruits, as revealed by comparative genetic analyses. Journal of Agricultural and Food Chemistry, v. 53, p. 3142-3148, 2005. PMid:15826071. http://dx.doi. org/10.1021/jf047927t

MA, Y. et al. The effect of freezing modes and frozen storage on aroma, enzyme and micro-organism in Hami Melon. Food Science and Technology International, v. 13, p. 259-267, 2007. http://dx.doi. org/10.1177/1082013207081776

MARKOVIC, O.; HEINRICHOVÁ, K.; LENKEY, B. Pectolytic enzymes from banana. Collection Czechoslovak Chemistry Community, v. 40, p. 769-774, 1975.

MARRERO, A.; KADER, A. A. Optimal temperature and modified atmosphere for keeping quality of fresh-cut pineapples. Postharvest
Biology and Technology, v. 39, p. 161-168, 2006. http://dx.doi. org/10.1016/j.postharvbio.2005.10.017

MATSUI, K. et al. Changes of lypoxigenase and fatty acid hydroperoxide lyase activities in bell pepper fruits during maturation. Bioscience Biotechnology Biochemistry, v. 61, p.199-201, 1997. http://dx.doi. org/10.1271/bbb.61.199

MCCREADY, R. M.; MCCOMB, E. A. Extraction and determination of total pectic materials in fruits. Analytical Chemistry, v. 42, n.12, p.1586-1588, 1952.

MORETTI, C. L. Panorama do processamento mínimo de hortaliças. In: ENCONTRO SOBRE MINIMAMENTE PROCESSADOS, 2., 2004, Viçosa. Anais...Viçosa: UFV, 2004.

PECH, J. C.; LATCHÉ, A.; VAN DER REST, B. Genes involved in the biosynthesis of aroma volatiles and biotechnological applications. In: BRUCKNER, B.; WYLLIE, S.G. (Ed.). Fruit and vegetable flavour: recent advances and future prospects, Abington: Woodhead Pub., 2008. 336 p. http://dx.doi.org/10.1533/9781845694296.4.254

PINO, J. A.; MARBOT, R.; AGUERO, J. Volatile components of watermelon (Citrillus lanatus[Thumb.] Matsum. Et Nakai) fruit. Journal Essential oil Research, v.15, p. 379-380, 2003.

RATNER, A.; GOREN, R.; MONSELINE, S. P. Activity of pectin esterase and cellulase in the abscission zone of citrus leaf explants. Plant Physiology, v. 44, n.12, p.1717-1723, 1969. PMid:16657261 PMCid:396333. http://dx.doi.org/10.1104/pp.44.12.1717

RILEY, J. C. M.; THOMPSON, J. E. Ripening-induced acceleration of volatile aldehyde generation following tissue disruption in tomato fruit. Physiology Plant, v.104, p. 571-576, 1998. http://dx.doi. org/10.1034/j.1399-3054.1998.1040408.x

RIZZOLO, A.; POLESELLO, A.; POLESELLO, S. Use of headspace capillary GC to study the development of volatile compounds in fresh fruits. Journal of High Resolution Chromatography, v. 15, p. 472-477, 1992. http://dx.doi.org/10.1002/jhrc. 1240150713

SHAMAILA, M. et al. Analyses of volatile compounds from strawbwerry fruit stored under modified atmosphere packaging (MAP). Journal Food Science, n. 5, p. 1173-1176, 1992. http:// dx.doi.org/10.1111/j.1365-2621.1992.tb11291.x

SOLIVA-FORTUNY, R. C. et al. Effect of minimal processing on the textural and structural properties of fresh-cut pears. Journal Science Food Agricultural, v. 82, p. 1682-1688, 2002. http://dx.doi. org/10.1002/jsfa.1248

THOMAZINI, M.; FRANCO, M. R. B. Metodologia para análise dos constituintes voláteis do sabor. Boletim da Sociedade Brasileira de Ciência e Tecnologia de Alimentos, v. 34, n. 1, p. 52-59, 2000.

VAROQUAX, P. et al. Change in firmness of kiwifruit after slicing. Scientia Alimentaria, v. 10, p.127-139, 1990.

VILAS BOAS, E. V. B. et al. Modificações texturais de tomates heterozigotos no loco alcobaça. Pesquisa Agropecuária Brasileira, v. 35, n.7, p. $1447-1453,2000$. http://dx.doi.org/10.1590/S0100204X2000000700020

WHITAKER, B. D.; SAFTNER, R. A. Temeprature-dependent autoxidation of conjugated trienols from apple peel yields 6-methyl5-hepten-2-one, a volatile implicated in inductionof seald. Journal Agricultural Food Chemistry, v. 48, p. 2040-2043, 2000. PMid:10888495. http://dx.doi.org/10.1021/jf991107c

WOLKEN, W. A. M.; HAVE, R.; WERF, M. J. van der. Amino acid-catalyzed conversion of citral: cis-trans isomerization and its conversion into 6-methyl-5-hepte-2-one and acetaldehyde. Journal Agricultural Food Chemistry, v. 48, p. 5401-5406, 2000. PMid:11087492. http://dx.doi.org/10.1021/jf0007378

YAJIMA, L. et al. Volatile falvor components of watermelon (Citrillus vulgaris). Agricultural Biology Chemistry, v. 49, p. 3145-3150, 1985. http://dx.doi.org/10.1271/bbb1961.49.3145 